\title{
Zinc Finger MYM-Type Protein 3
}

National Cancer Institute

\section{Source}

National Cancer Institute. Zinc Finger MYM-Type Protein 3. NCI Thesaurus. Code C101619.

Zinc finger MYM-type protein 3 (1370 aa, $152 \mathrm{kDa}$ ) is encoded by the human ZMYM3 gene. This protein is involved in histone acetylation. 